\title{
Preindustrial Water Management in Eastern Africa
}

\author{
Chapurukha M Kusimba* and Sibel B Kusimba \\ Department of Anthropology, American University, USA \\ Submission: February 06, 2017; Published: March 23, 2017 \\ *Corresponding author: Chapurukha M, Department of Anthropology, American University, Washington, Dc 20016, USA, \\ Email: kusimba@american.edu
}

\begin{abstract}
Africanist anthropologists have intensively studied land use and land rights, but rights to water are often more fundamental; managing water is often the centerpiece of social organization related to the environment. Not surprisingly, water management has been the center of many anthropological approaches to the origins of social complexity. Our paper will discuss how African communities managed, used, stored, and distributed water and how they developed intensive agricultural practices in relatively arid environments. We examine two comparative examples from Eastern Africa in detail: hill slope irrigation systems and rice farming in Madagascar.
\end{abstract}

\section{Introduction}

Water is life, humankind's best friend and, sometimes, one of worst foes. Water's presence or absence, abundance or scarcity has shaped and continues to shape daily life, ecological, and geopolitical landscapes. From foragers to pastoralists, farmers and urbanites, water has been a key component of daily life.

This article examines water management systems and their social implications in Eastern Africa. We will examine two case studies in-depth. First is the practice of furrow-irrigation along hill slopes in East Africa, known ethnographically among the Taita of Kenya and represented archaeologically by sites in Kasigau [1], Engaruka [2] and Nyanga in Zimbabwe [3]. In these cases, irrigation was part of an agro pastoral system that included terraced fields, pen-feeding of cattle, and manuring. Ethnographic cases provide examples of how kin and community based networks provide labor to maintain and extend these systems [4,5]. The second case study is rice farming in Madagascar, a highly labor-intensive effort involving saturation and draining of seedbeds, transplanting, and furrow irrigation. These two very different examples give some idea of the range of social and technological strategies developed in African societies to manage water. They also highlight the consequences of water scarcity from a variety of factors, both natural and cultural.

In the ancient world, control of water was bound up with local and regional systems of water management and was a crucial part of the origins of ruling classes and social inequality in many areas [6-9]. Managing water requires understanding and manipulating the environment and organizing the human environment, whether through institutions, consensus-building, kinship models, or coercion [10]. Water management strategies were a crucial part of the long-term history of civilizations $[11,12]$. Consequently, approaches to water in ancient societies have involved all aspects of the social, material, and ideological realms [13].

In many local systems kinship and community organizations develop rules and regulations that guide access to water and water catchment areas, for example, wetlands, swamps, meadows, and dambos [14]. In complex societies elites and administrators control water access. In these areas, social traditions and rules of water use and control must necessarily be dynamic and adapt to cycles of water abundance and scarcity and to changing social relationships as well. They also ensure that land is equitably distributed to enable every citizen access to water resources.

The best way to consider human use of water is through the idea of a domesticated landscape [15]. All humans, to live and thrive in their environments, transform their environments by manipulating its resources. As hunter-gatherers adapt the availability of water, they can also dig and expand dry-season waterholes. Agriculturalists change the environment and its water in even more profound ways. While rain-fed agriculture is suitable on fertile hill slopes, intensification of farming has meant making irrigation ditches, raised fields, and other features that concentrate and move water. These features in turn change how the landscape is sculpted by water over time. On a human level, they demand an organization of labor of varying sizes; in some cases households or local groups manage their own water, 
and in others regional or state level decisions control water and labor around it. Consequently even a "natural" event like drought or famine is in fact the "outcome of a political ecology $[16,17]$ ": a combination of natural environmental conditions, land use practices, and the organization of labor, markets, and social power relations. The story of humans and water is consequently a cultural-ecology approach to human relationships with the environment $[18,19]$.

Much archaeological theorizing on the development of social complexity has concerned the role of water in complex, highly centralized societies in the ancient world. Even though it has been criticized, Wittfogel [9] hydraulic society theory argued that social control of large irrigation systems became the basis for the origins of government and social inequality [20-22]. Although Wittfogel probably overstates the case and although in many areas such as China, elite political control emerged before the centralized control of large-scale irrigation systems. However, the role of irrigation in political evolution is still very important. New attention is being paid to decentralized or heterarchical social relationships, in which social and political power are diffused throughout a society in the form of different offices of power, complex social networks, corporate and descent groups, and so on. Many ancient civilizations were imperfectly centralized, and the diffuse or flexible execution of power might fit a variety of ethnographic and archaeological case studies better $[23,24]$.

Scarborough [13] has argued that decentralized webs of social relationships tend to develop when agricultural manipulation of water and the landscape is relatively slow, for example in the case of slow in situ population growth in an area. This type of development he terms accretional. Expansionist development, by contrast, is rapid social growth because of high population growth, innovative technology, or political expansion.

Whether the rate of change is slow or fast, societies also tend to vary according to whether they tend to invest in labor relationships, technological relationships, or both. Societies that have highly efficient divisions of labor based on the extended family or other local group that manages water control are called labor tasking societies [13]. These societies tend to develop when skilled labor is abundant and farmland is limited, and not surprisingly they are often associated with accretional (slow) development. However, they tend to invest in maintainable and long-term strategies of food production and environmental manipulation that are extended and developed with each generation, such as terraces or irrigation canals. By contrast, there are societies that tend to invest in labor-saving technological devices, especially where labor is limited but land is not. These "techno tasking" societies tend to experience greater social change and a more dynamic manipulation of the environment - the expansionist pattern.

In between the techno tasking and labor tasking mode is multitasking, that tends to employ labor in a flexible way and does not have a large investment in technology. Multitasking systems tend to resist specialization on one crop or way of making a living, and consequently they tend to resist long-term investments in irrigation canals or other labor-intensive commitments. They tend to be found in unpredictable environments where land is abundant; not surprisingly they are associated with extensive rather than intensive use of land and resources. These types of societies are intermediate in terms of the pace of development and change. In sub-Saharan Africa, these types of societies are common. In general, the use of canals, irrigation, and other intensive strategies are relatively rare where resources are unpredictable and mobility and shifting land use are possible $[13,20,25,26]$.

Scarborough's focus on rate of change over time and the contrast between labor-focused and technology-focused land and water use is a compelling way to rethink water use and the pattern of social evolution. A society may use both labor- and technology- focused strategies, for example there may be more use of technological solutions among elites and more use of labor-based solutions among the poor or marginalized.

\section{Ancient Irrigation Agriculture in Eastern and Southern Africa}

The first case study we will examine is downslope furrow irrigation systems in East Africa [1,27,28]. These would fit the "multitasking" model of Scarborough [13]. They are adapted to seasonal drought, relatively low rainfall, and an abundance of land. In general, intensive agricultural practices, of which water management is a part, are relatively rare in sub-Saharan Africa. Arid climate plays a role in the preference for "extensive" strategies that involve high mobility rather than intensive strategies that commit to modifying a place on the landscape long-term. Rain-fed agriculture also uses strategies to conserve water, such as weeding, which reduces evapo-transpiration. Nevertheless, poor agricultural productivity has been a constraint important in many areas of sub-Saharan Africa. Droughts lead to a severe reduction in the quantity and quality of water. A decrease in the availability of water may affect people, wildlife, and plants and create intense competition for water and water dependent resources. Stability in the ecosystem depends upon accessibility to perennial water sources.

Most of the time this accessibility is accomplished by moving people to where the water is available. The histories of East African peoples are replete with examples of migration, relocation, and resettlement, with attendant ethnogenesis and assimilation. People moved for a several of reasons but chief amongst them was climate change, which caused famine and pestilence. Often when people moved, they would settle, mostly seasonally but sometimes permanently, amongst their nearest neighbors with whom that head previously relationships. In East Africa, the 18th and 19th centuries were characterized 
by an unstable climatic shift, which caused long periods of drought. The Giriama, Akamba, Swahili, Oromo, and Taita oral traditions recall the efforts made to deal with this crisis and how it threatened to unseat long established traditional systems of interaction and intercommunity cohesiveness [29,30].

Iliffe [30] and Ochieng [31] argue that famine was the biggest challenge in pre colonial East Africa, driven sometimes by poor soils but mostly by irregular rainfall. In our research area of Kasigau, for example, oral histories are laden with catastrophic famine [29,30,32-34]. Strategies to adapt to it were often social rather than economic. Famine was the most frequent impetus to social migrations and to exchange practices whereby cattle wealth was exchanged for food. Cattle were an important insurance against the risk of agricultural failure. By loaning stock or exchanging it through bride price, a family could increase a social insurance net of friends and relatives whose help could be elicited during famine [35]. In this way, the need to invest in advanced farming was reduced. Wherever techniques like terracing, manuring, crop rotation, mixed farming and swamp farming could be used they were; in many other areas, extensive practices and social mobility were the most frequent responses to irregular rainfall.

In the ethnographic record of Africa, there is abundant evidence concerning water use and water access and the social and political relationships that were defined around water. The ability to accurately predict water, availability, scarcity, and abundance, and to find water, or bring rain was a highly -regarded sphere of knowledge and religious specialty. It is not surprising that ritual specialists involved with water were very powerful. Rainmakers and well-diggers were highly sought after and revered individuals. Among the Bukusu and other East African groups diviners and rainmakers were given tribute of beer and grains and became wealthy and prestigious [36]. Rain makers exercised political decision-making as well, as headmen and leaders of war would ask their blessing when choosing to relocate a village or wage a war [36]. Other specialists could find water in arid environments; the Oromo pastoralists held sway the knowledge of well-digging. They developed an elaborate method of harnessing water from the baobab trunks and placing wells a few inches from the sea water level. Their reputation was so widespread that Oromo well-diggers were a highly sought after hydrologists, who were contracted by diverse peoples, including their traditional enemies the Amhara and Swahili.

Landscapes of settlement in Iron Age Africa included use of a variety of areas. Homesteads would be positioned according to calculations of a variety of target resources, including water sources, iron ore sources, arable and grazing land, wild plants and animals, medicinal plants, salt and other minerals, shelters for guarding cattle or for defense, and timbers for building, cooking, and iron smelting. Agricultural and water-management practices also should be understood against the backdrop of iron smelting technology, prevalent in many areas. As the technology of iron smelting became widespread, its demand for charcoal was accompanied by dramatic deforestation in many areas. The consequent loss of stream and river water was considerable in many areas, and had an impact on the ability to use water from streams. Schmidt's work among the Haya has shown the dramatic impact on the environment and on water resources of long term iron smelting technology over 2500 years in northwestern Tanzania [37-39].

Iron smelting uses large amounts of charcoal, which is manufactured from felled trees in a laboriously slow covered burning. Initially, pollen and charcoal analysis showed that Early Iron Age iron smelting furnaces, beginning around 300 BCE used a variety of mature forest trees for making charcoal; by 300 $\mathrm{CE}$, the diversity of trees used was less and included secondary species. Deforestation is also documented in pollen profiles over this time. By the middle to late Iron Age, swamp forest trees were preferred for making charcoal, indicating the few remaining sources of trees were being targeted for iron smelting. In Schmidt [39] ethnoarchaeological work, the trees from the genus Miscanthidium and Syzygium are preferred; these areas are limited to swamps and were just as limiting a resource on the scale of iron production as the ore itself. Other trees that grow in valleys with high water tables were also used. Archaeological surveys indicate communities were often established on the margins of swamps and forested valleys.

Early Iron Age settlement beginning around 600 BCE was accompanied by intensive iron production, deforestation, soil erosion and depletion. Around $600 \mathrm{CE}$, settlement moved to lakeshores and iron working appears to have stopped in the area, perhaps because of deforestation; in the thirteenth century, settlements returned to the interior, this time with abundant cattle as part of the economy. By the late Iron Age, smelters were using Miscanthidium grasses, a more efficient and more rapidly renewable source of fuel. In any case, iron smelting like farming required fuels from well-watered areas and tethered settlement to these areas.

As populations grew and the landscape was gradually cleared, the locations of these sources changed; with deforestation, sources of water were reduced and swamplands and other nonarable areas became important remaining sources of fuel. In a landscape already semi-arid in many areas, the Iron Age may have reduced the availability of water in many areas.

Down slope "hill-furrow" irrigation systems, basically run by gravity and fed by rivers running downslope, are found in several of places in northern Tanzania and along the Rift escarpment in Kenya and Tanzania [25]. They are found on Kilimanjaro and the Pare and Meru Mountains [40] in the Sonjo villages about Lake Natron, which may be a related group of peoples $[21,41]$ and in lower Marakwet south of Lake Turkana, where canals are led off a series of rivers descending a steep escarpment [27,28], and at the northeastern end of Lake Eyasi on Oldeani Mountain [2]. 
These highly specialized agro pastoral systems were expertly adapted to arid areas of highly seasonal rainfall and they were closely maintained and adapted over centuries in most areas. Their distribution was if anything greater in antiquity; in many regions lacking in stone, furrow agriculture used earthen channels or wood-lined channels, and due to the continued practice of agriculture in so many regions, many remains of irrigation systems are probably no longer visible. In these many regions remains of irrigation likely date to the last 500 years. They show distinctive hiatuses beginning in the late 19th century in many areas. Perhaps British colonialism or environmental change or a combination of events caused the breakup of these intensive slope systems of irrigation agriculture.

\section{Engaruka}

Engaruka in Northern Tanzania is a major site of 2000 hectares stretching for 9 kilometers along the base of an escarpment of the Great Rift Valley. The site dates from 14001700 AD [42]. Engaruka's estimated population of nearly 5,000 people lived in seven villages and subsisted on sorghum and other crops and manured their fields from stall-fed cattle.

Today, Engaruka receives $500 \mathrm{~mm}$ of rainfall annually; its relatively arid climate is habitable by pastoralists; but unsuitable for sorghum farming. How did ancient Engarukans successfully develop and sustain such high levels of intensive land use: irrigation farming and cattle husbandry in an area that by today's standards can only sustain transhumant pastoralism? The site is sculpted by the remains of a system of ancient fields and carefully engineered irrigation works, cultivation plots being divided and terraced with stonework from the hillslope. Intensive and sustained research by the British institute in Eastern Africa has reconstructed a system of land use based on irrigation farming at Engaruka that provides testimony to the ingenuity of ancient farming systems and practices in east Africa [26,43,44]. Running down the Escarpment is the Engaruka River, and parallel to it at least four seasonal streams. Irrigation furrows were dug that led river and stream water to an area of terraced hillside $9 \mathrm{~km}$ long. The Engaruka system channeled seasonally heavy rains and used gravity exclusively, engineering a gentle slope that could bring water through rock-lined furrows through feeder canals to farms. The canals are still visible [2].

The Engaruka system included main arteries that fed smaller feeder furrows. The system was clearly actively maintained. Sutton [2] observed places where alignments of the main feeder furrows were changed and rearranged. Rather than simply being extended, the irrigation system was improved, modified, and in some cases completely reorganized to influence productivity and irrigation efficiency as the supply of water and the extent of irrigated land changed.

Circular cattle pens made of rocks are found within the irrigated fields, where manure could have been most efficiently applied. Human settlements were located near the top of the escarpment along the main, upslope water canals, where some water was doubtless diverted for household use. Interestingly a village-based mobilization of labor, which combines both a kin and village based social group, is still relied upon among the Taita who maintain terracing and irrigation canals [4]. Engaruka homesteads used paving of dry stonework for house floors and walls. Cattle appear to have been penned up in stone-circle kraals located in the middle of fields rather than underground of the homestead. This may indicate little concern over raiding, and probably smaller overall herd size. The Engaruka adaptation to an arid environment of periodic drought is impressive but not singular. It recalls the irrigation systems of similarly arid Coastal Peru [12].

\section{Nyanga}

The Nyanga area of eastern Zimbabwe has a large complex of late Iron Age villages showing a variety of techniques of stonework terraces, farmsteads, irrigation canals and furrows over an area of 5,000 square miles. The area shows a long-term example of water maintenance in the context of intensive agro pastoralism [45] and dates from the 13th to the 19th centuries, a period where the area was under the loose control of a series of chiefdoms.

Intensive farming in this region was practiced on welldrained hill slopes, using manure to increase soil fertility. Some farming was also done in lowland areas using broad ridging, but the hill slope soils were much more fertile. Terraces were constructed with dolerite rocks and soils found abundantly in the area to stop runoff and conserve soil. The stones were also used in the construction of homesteads.

The Nyanga highlands are a north-south series of hilltops with steep escarpment on both sides. Flat plateaus extend at the base of these escarpments and abundant water in the highlands becomes channeled into a series of rivers leading south, west, north, and southwest. There are also many permanent streams that descent the escarpments and valleys. This ample water flow is the basis of the elaborate system of water furrows developed along the terraced slopes. On the plateaus and escarpments of this area, there are waterlogged areas, valleys, and bogs which were diverted into cultivated areas by constructing cultivation ridges called mihomba.

Settlement in this area appears to have begun in the highlands around $1300 \mathrm{CE}$, where remains of hilltop villages around $300 \mathrm{~m}$ in maximum dimension include terraced house floors and lowwalled enclosures. Around $1600 \mathrm{CE}$, settlement shifted to lower elevations where people built pit structures and pit enclosures in the highlands and on lower plateaus and surrounding plains, where stone-lined pits $9 \mathrm{~m}$ wide and $3 \mathrm{~m}$ deep served as cattle pens built adjacent to habitation structures.

The more well-developed homesteads included circular 
living structures arranged in a cluster- including separate homes for wives of the household and separate kitchen structures that were built on reinforced extensions of hillsides and built over an underground cattle pen accessed through a stone-lined tunnel. This clearly defensive plan included a trap door from the largest structure to the level below, where logs could be dropped to close the entrance and thus protect cattle as well as collect their dung for manuring the fields. Inside the round huts human use areas were separated from stone-lined goat pens. Other sites include forts with thick wall enclosures and iron working sites. Clearly the Nyanga complex was an extensive settlement on the landscape, based on polygynous extended families and employing tremendous investment in dry stonework to protect cattle, presumably from raiders. The Nyanga complex also includes and iron working sites found in and among the network of furrows, terraces, and other features of water management.

The agricultural activities of ancient Nyanga involved deliberately shaping the landscape over hundreds of square kilometers to modify the movement and location of water running off of the highland areas and out of waterlogged areas. The most obvious strategies were: steep hill slope terraces, lowland cultivation ridges, and water furrows. Terraces are common on rocky hill slopes and vary in size and depth. They are found below $1700 \mathrm{~m}$ where traditional crops may be cultivated. They are found surrounding pit houses and enclosures.

There are also extensive systems of ridges and ditches in lowland areas that lack rocks. They are roughly 7 to $10 \mathrm{~m}$ wide and extend in bands across at least $60-70 \mathrm{~km}$ to the west and east out of the main highland ridge. Oral traditions suggest that these ridges were used to form water logged long and narrow seed beds where tsenza (Plectranthus esculenta) or Livingston potato, majo, a variety of taro or cocoyam, and other garden vegetables were grown.

Furrows divert the many permanent springs into terraced fields, open fields, and homesteads. Some were more than $2 \mathrm{~km}$ long and extended across drops of $80 \mathrm{~m}$ or more. Some large furrows were made with massive earthen banks and subfurrows leading into open fields. These would have involved large labor investment and sometimes included reservoirs up to $12 \mathrm{~m}$ long and $7 \mathrm{~m}$ wide cut into the slope and reinforced with stone along the slope.

The Nyanga people used a diverse landscape that included well-watered highlands, terraced hillslopes, and valleys that often included vleis. They used water management to modify the movement of water around these areas. The system was based on cow and goat pastoralism with a relatively small number of cows per family, perhaps less than five, and goats kept for meat. Manure was essential for enriching leached soils of the lowlands and highlands. Farming included sorghum, millet, cowpeas, beans, squash and castor oil, roots, pumpkin and green vegetables. Intercropping would have been practiced as well.
The social organization of the homesteads found dotting the region's furrowed and channeled hillsides is often revealed by the spatial organization of rows of stone boundaries. Still visible lines of stones suggest a holding of 0.3 to 0.4 hectares per homestead, but with a lot of variation in wealth and family size. Families also may have had subsidiary plots in outlying areas, perhaps areas fed by ridges in the lowlands. According to Soper [45], grazing rights would have been allocated on a communal basis. In general, a decrease in the intensity of cultivation would take place from gardens (continuous production) to infields to outfields - which might lay fallow the most. Still there was probably a degree of shifting cultivation particularly in the lowlands.

Like Engaruka, the Iron Age habitation of Nyanga complex probably lasted a few centuries. The villages began on hilltops and crests in the 14 th and 15 th centuries. These were nucleated villages huddled on the high hilltops of the main northern range, with populations of perhaps a few dozen up to several hundred in the case of Chirimanyimo, the largest of these villages which appears to have had some chiefly authority. Land around these villages was cleared for farming.

Soper [45] argues that farmers would gradually have returned to reoccupy earlier terraced settlements after an adequate period of fallow. Soper notes that broken pieces of earlier homes were recycled into new housing. The Nyanga strategy is thus a combination of extensive land use with investment in agricultural intensification and modification of water resources on the landscape. In the 16th and 17th centuries, there was a change in the settlement pattern to more dispersed villages of individual homesteads within the same territory at slightly lower altitudes, possibly due to climatic shift. Cattle holdings were probably greater, thus explaining the investment in the stone-lined underground cattle pits. This also indicates that there was more available pasture land as the forest was cleared.

There are glasses and copper beads here, showing trade contacts or perhaps local manufacture. After the 17 th century, the pit houses are more common. Family homesteads are distributed in dispersed village groupings, with spacing from $30 \mathrm{~m}$ to $100 \mathrm{~m}$ or more. The village of Nyangui had 30 of these homesteads. Sometimes double pits were made for large holdings of cattle. These groups of homesteads were fed by water furrows, showing community cooperation and management as among the Taita.

Scattered walled forts with internal house structures are interspersed with the pit structures. These may be defensive or the homesteads of chiefs or headmen. After the nineteenth century, pit structures are abandoned in the highlands. In some regions stone walled sites are built in between large boulders and outcrops with granaries constructed in caves. Lowland enclosures continue into the 18th and 19th centuries. These were loosely clustered, according to Sutton, and homesteads were linked through terracing to walled track ways through 
fields that allowed livestock to access grazing areas. Stone lined divisions marked the land of different homesteads.

While the Nyanga terrace builders used intensive agricultural techniques, especially terrace-building and manuring, it was still part of a shifting land use strategy. As Soper notes, the region included a small isolated population distributed in farming villages. However, labor would be needed in relatively large groups to make and maintain terraces, ridge systems, and homestead construction. In comparing Nyanga to Engaruka, it is interesting that the Nyanga homesteads were more dispersed among irrigated fields [45], while at Engaruka villages were nucleated upslope from the fields. This does suggest different idioms for mobilizing agricultural labor, which may have been based around the household in the Nyanga case (which owned nearby lands but also held rights to fields downslope from the household) and around the village community in the Engaruka case. Furthermore, there is more evidence of social stratification at Nyanga, its households showing more variation in size of both habitation areas and cattle pens; furthermore, the walled "fort" sites may also have been chiefly residences. One might speculate that wealthier, larger households may have used indentured labor from less wealthy households to manage water systems. This contrasts with the smaller, more egalitarian pattern at Engaruka, where nucleated villages may have coordinated maintenance of water systems through lineage and village headmen as is today the pattern among the Taita [46].

At both Engaruka and Nyanga, the relatively small number of habitation sites (whether nucleated villages or dispersed homesteads) is coupled with a relatively wide extent (several kilometers) of terracing and other agricultural and settlement remains. As Soper notes, both cases were probably a "blend" of highly mobile, extensive farming practices where habitations and active fields were moved every few years, with labor investment in irrigation practices. Soper [44] explains: "the fields had a more or less limited fertility span and that construction was therefore an ongoing piecemeal process, with new areas being brought into use as old ones were abandoned. Eventually all suitable land available would have been exhausted and it would have been necessary to move to a new location." Soper and Sutton find evidence that abandoned fields were reoccupied, terraces and furrows reconfigured, and homesteads rebuilt from recycled materials as long-term land use shifted settlement. Intensification was thus combined with extensive or shifting land use.

At both Nyanga and Engaruka, another factor was playing out among these farming communities. Both were drawn into trade networks that led ultimately to the East African Coast that brought Coastal and international products, such as cloth and beads, to the African interior. Agricultural surplus could be bartered for trade goods and was in some areas an impetus to agricultural intensification. In the Kasigau area [33], connection to the Coastal ivory trade and slave trade accompanied evidence of intensification and irrigation practices.

\section{The Terraced Villages of Mount Kasigau, Kenya}

Our third example is drawn from Kasigau in the Tsavo region of the Kenya. We have carried out sustained research in Tsavo since 1997. At Mount Kasigau, an inselberg covering 25 square kilometers on the southeast region of Tsavo is a landscape shaped by long-term human occupation. Some areas have been intensively modified. Others evince low intensity activities such as grazing. The variation in landforms and environment created a community of different types of sites, including rockshelters, terrace fields and villages at the base and on top of the mountain $[33,34]$. Based on site distribution and intensity, we estimated that Kasigau population size at its zenith in the 14 th century was similar to that of Engaruka [1].

Kasigau is drained by several streams and springs which have sculpted the mountain into ridges. These streams hold water for six months after the annual long rains. Most of the springs drain into the Bungule River and Mwatate River which drain into the Rukinga dambos. Bungule spring is perennial but dries up during severe droughts. Today, Kasigau includes village clusters, isolated homesteads (some of which are on terraces), and peripheral pastoral camps. Large and very old mango and coconut trees along the streams and springs abound in Kasigau. Further into the plains, one encounters tamarind trees that are equally old. Abandoned orange and lemon orchards (whose fruits are too bitter to eat even for the curious monkeys and baboons) are common on the hill top. There is no doubt that Kasigau was until recently a domesticated landscape that is returning to its wild from.

Like Engaruka, Kasigau receives less than $500 \mathrm{~mm}$ of rainfall annually. How were the people of Kasigau able to develop and sustain intensive irrigation field of crop and animal husbandry? Being only $100 \mathrm{~km}$ from the Iron Age port towns of the East African Coast, Mount Kasigau, like Engaruka, took advantage of the regional economic boom provided by international maritime trade to invest in large-scale agricultural and livestock management. Being located only 3 to 4 days from the metropolis of Mombasa, Mount was an ideal place for establishing a collecting and distribution center for the then booming regional trade in the Indian Ocean [47]. The archaeological evidence shows that the development trajectory of Mount Kasigau from a small hunter-gatherer settlement into a large inland town that served as a major collection and distribution center for trade. As its trade and relationship with the coast and other outlying regions grew, Kasigau's prominence also expanded, giving its residents opportunities to expand trade and invest in infrastructure necessary for maintaining their profitability of regional trade. The principle trade items exchanged included beads and cloth for grains, honey and beeswax, fresh fruits, milk, ivory, rhinoceros horns, animal skins among others. Arrival in 
Kasigau was a sign that home was only three days away from the Coast.

How and in what ways did the Kasigau people respond to the increasing demand for provisions by coastal and hinterland merchants? How was labor mobilized to build and maintain terraces? What was the nature of land tenure system, intracommunity and intercommunity relationship, political and social organization, and population dynamics?

The archaeological data we have thus far suggests that Kasigau peoples intensified production in agropastoral, agrarian, and hunting economies in order to meet the demands imposed by long distance trade. Much of the south and west facing slopes of Mount Kasigau east of the village of Bungule and north of the concentration of rockshelters around Bungule 1 had been terraced. These now abandoned settlements consisted of about 5 columns of at least 20 terraces separated horizontally by the streams flowing from natural springs further up the mountain. These streams would have not only provided fresh water for drinking, cooking, washing, and other household tasks, but could also have been used for irrigation if necessary. Easily identifiable from a distance, the terraces were frequently marked by useful trees such as baobab, mango, and tamarind and steps could even be seen in the heights of the tree cover (which could indicate abandonment at roughly similar times). The archaeological evidence recovered from Kasigau shows that intensification occurred in three visible areas: pen feeding of cattle for manure and secondary products, terraced farming; and intensification of iron production.

The average width of the terraces was 30 meters but their length varied according to the irrigation canal and steepness of the slope. Presumably each terrace belonged to one household or extended family the terrain of the land made it possible for the residents to subdivide the land following irrigation canals. Terraces prevented erosion and demarcated family and house hold property. Terraces were erected with stones and mud after the area was leveled up to make possible the construction of houses and subsistence agriculture. All the stones were locally available but their construction required considerable investment, time, skill, and labor mobilization. The quality of skill in erecting these terraces gradually improved with time. The terraces ran in an east-west direction from one edge of the canal to another.

Each terrace had a house and a garden. As the number of terrace residents increased, more houses were added to the terrace and the gardens relocated towards the canals. At some point in the settlement history, houses filled much of the terrace forming a small town or hub in the hills. Some areas became very congested. All the houses were round, oval, or cylindrical. The primary building materials were tree posts and branches, stone and mud as mortar. The roofs were thatched with grass and coconut fronts. The floors were packed together with mud, sand, and concrete. They were never "cemented". Neither was dung ever used as a cleaning agent of the floor like in other agropastoral communities. The settlement appears to have been abandoned abruptly. The settlement has been little disturbed since its abandonment.

This is illustrated by the fact that:

A. Grinding stones and pots, most of which were still in use, were left in the houses at the time of e abandonment. Few grindstones were visible;

B. The fire hearths illustrated by three traditional hearthstones were visible above ground; and

C. In a few houses, there were whole pots that had only been recently disturbed.

Before terraces were built, the area was excavated and leveled until they were flat and level. The terrace was built from rocks and soils collected from the excavation. The terrace consisted of rocks held together by wet earth serving as mortar. The terrace was made firmly both to prevent soil erosion and thus protect the fields. Each terrace extended from one edge of the canal to the next. Farms and gardens were often placed closest to streams and irrigation canal for easy irrigation. Houses were built in the higher and drier areas of the terrace.

According to elders interviewed, the system of land tenure recognized and respected the individual rights to terraced land. In contrast, non-terraced fallow land was communally owned. Anyone would clear virgin forest and plant their crops. Although only use rights were recognized, elders determined the overall distribution and use of land.

The terraces were of two types: large, relatively flat spaces with stone retaining walls of about 1-1.5 meters in height and shorter, more angled terraces with retaining walls of at most 30 $50 \mathrm{~cm}$. One hypothesis is that the larger terraces are the sites of homes and other residential activities, while the small terraces are for farming and/or horticulture [46]. The large flat terraces had clusters of two or three hearthstones (usually with a grindstone directly adjacent), multiple grindstones, and occasional complete ceramic pots. Two possibilities were proposed for the frequent hearthstone-grindstone co-occurrences. First, grindstones may have been used by the fire for convenience in cooking. However, the proximity of the stones to the fire is such that use would be impractical due to the heat. An alternative possibility is that grindstones were stored on rafters or in raised granaries above the fire and fell with the collapse of the house. Most of these grindstone-hearthstone occurrences were associated with small mounds or slightly raised linear mounds, which represented households or enclosures. Terraces frequently had more than one such association indicating multiple houses, probably for various elements (wives, sons' families, etc.) of an extended family. 
One set of terraces (Bungule 29) consisting of two large flat terraces and the series of smaller intermediate terraces between them was selected for clearing, mapping, and excavation. The southern (downslope) terrace was designated Bungule 29A while the northern (upslope) terrace was designated Bungule 29B. The intermediate terraces were given no specific designation, nor were they cleared or mapped.

The most prominent feature of Bungule 29A was a shallow channel running north south through almost precisely the middle of the terrace. At the southern end, the terrace wall was absent, and it seemed likely that the gap was left purposefully. Several meters to the south of the terrace was a pit $\sim 1.5-2 \mathrm{~m}$ deep lined at the edge with stones. Access to this probable latrine could have been a reason for the gap. On the terrace itself, there were several small circular mounds, which may be house remnants.

The Kasigau terraces themselves represent a community, but one which was loosely aggregated. Terraces suitable for housing are irregularly spaced with areas for cultivation in between. The Bungule terrace system makes it difficult to begin to draw conclusions about the community. At this stage it is really only possible to note the tremendous amounts of labor which must have gone into terracing such a large area (probably hundreds of terraces). While some (e.g. Bungule 29B) were occupied more recently, the tuyeres and slag recovered from terrace deposits indicate earlier dates for the first development of these areas.

The terraces differ in almost every respect from the rock shelters. The building strategy contrasts sharply not only in style, but also in materials. There is only one example of plastering from the rock shelters (Bungule 28A). Substantial stone construction on the terraces is only present for the retaining walls, and differs markedly in style. Even the little information we have on the earlier terrace occupations fails to conform: slag, bone, and ceramics were not recovered in similar quantities from any of the enclosure sites. Whether this indicates an earlier date for the shelters or simply different subsistence and craft production systems cannot be judged without the radiocarbon dates. It is only with more substantial research that the reasons for these contrasts can be fully delimited.

\section{The Impact of Rice Culture on Biodiversity in Madagascar}

Our second example comes from the central highlands of Madagascar. In contrast to Engaruka, Nyanga, and Kasigau, the central highlands of Madagascar receive an average of 127 centimeters of rain annually [48]. The central highlands, home to the Betsileo, Merina, and Sihanaka, saw the development of intensive farming based on irrigation rice and cattle husbandry. Abundance of irrigable land and pasture favored the development of large nucleated villages on the hilltops and terraced fields in the valleys and down slope [49]. Settlements in the highland are located on hilltops. One to nine enormous, concentric straightsided ditches elaborately fortified these settlements, sometimes as deep as thirty feet, with a wall or, in the south, cactus hedge on the inside. This settlement pattern was abandoned in the nineteenth century when the region was pacified and leadership consolidated under the Merina Kingdom.

Linton [49] recorded oral histories of the complex process of rice farming. Seed beds were usually made on hillsides, one above the other. They are surrounded by little walls of earth which keep in the water and also serve as paths when the fields are flooded. The preparation of the beds takes a long time. First little canals are dug across them to dry them thoroughly. Then the earth is cut out in square clods like bricks, and these are piled up to dry and air. When they are quite dry they are broken and mixed with manure and the beds are leveled and flooded ready for the planting. The fields are prepared in the same way, although the clods are not cut so carefully, and at the last cattle are driven back and forth over the flooded field to make the mud smooth and soft. The digging is done with a long heavy spade. His spade is a matter of pride to every farmer...Formerly rich peoples' fields were worked by their slaves. Poor people gathered together and worked all the fields belonging to the family one after the other. The man whose fields were worked that day made a big feast for everybody in the evening.

The seed for the first crop is sown in April or May, that for the second crop in September. The blooming of the Ambiaty is a signal for the planting of the second crop, but it stays in bloom about a week and families who could afford it would consult a diviner to find which day was most propitious. Rice will still sprout after several years, but it is best to use that from the last harvest. Ripe grains that are very dry are selected and stored in earthen jars. When planting time comes, the seed rice is soaked in water for three days, until it sprouts, and is then sown broadcast on the flooded seed beds. Our ancestors never sewed the last handful of seed rice. They carried it home and put it in the northeast corner of the house, where the family charm was kept and the offerings to the ancestors were placed. The man who was carrying it had to go home by the shortest road and could not turn aside for anything. If he did the harvest would fail.

As soon as the seed has sprouted well the water is drawn off and the seed bed is covered with manure. A few days later the water is let in the morning but drawn off at night. This is left up for two or three weeks, after which the water is left on the bed until the young rice is ready for transplanting. This is women's work. They uproot the plants, time them in bundles, and carry them to the fields, where they plant them again in the soft mud, pressing them in with their fingers. The rice has many enemies. While it is still in the seed beds it is eaten by rats and mice if the beds are dry, and by wild ducks if they are wet. We build clay pillars at the corners of the seed beds, whitening them with earth and putting dried banana bark on them.

Leaching, erosion, and natural soil deterioration in the central highlands of Madagascar have exerted tremendous stress on soil fertility leading to severe decline in agricultural output. 
Crop failure and famine have become regular and common. To prevent constant migration and relocation, the central highland peoples developed a very complex method of collecting and curing dung for fertilizing their terraced fields. The Merina set up separate areas above ground in the homestead surrounded by a perimeter wall. While the Betsileo built sunken corrals not dissimilar to those of the Nyanga.

In order to investigate the productivity and environmental impact of the present-day system of intensive rice irrigation agriculture and cow pastoralism, we tested the hypothesis that highland Malagasy reverence of cows was largely due to the role cows play in maintaining a viable rice culture. Rice growing is an extremely labor-intensive undertaking. Maintaining rice paddies and terraces, controlling and managing the distribution of water during the sowing and rainy seasons, and soil erosion are labortasking. Terracing the land to create manageable paddies is a precondition for rice growing. Terraces need to be continuously maintained almost all year round. Since the paddies are submerged in water for most parts of the year, leaching is often a problem thus the farmer most ensure that the fertility of the sold and integrity are maintained. Successful rice growing minimizes shifting cultivation or the slash and burn techniques of crop husbandly. Therefore to maintain the integrity and fertility of rice farms requires regular fertilization annually.

Cows provide manure necessary for replenishing the rice fields. Farmers invested heavily in building complex corrals to efficiently collect and cure dung for fertilizing rice fields. The Betsileo corrals, for example, are sunken structures; their walls are lined with stone cut basalt or bricks. They have one entrance, usually facing the homestead. The entrance inclines at an estimated $40^{\circ}$ angle. The entrance is secured by strong posts, which have a lock. Usually there are 3-4 locks per corral. The elaborate design consisting of a sunken corral, stone lined walls, an inclined entrance, a gate with locks, points to the importance of cattle to Betsileo way of life. Sunken walls are the most efficient means to harvest and process dung into manure for the rice fields. With the exception of the Vivericula indica (ampaha), Madagascar does not have many predators and due to their large size. Cows are not natural prey of the ampaha. Therefore we assume that these corrals protect the cows from thieves since without cows they would be no rice fields but one can buy a cow to sacrifice for an ancestor from anywhere. The evolution of sunken corrals typifies the genius of Malagasy people in successfully creating and maintaining a system of managing what is an otherwise resource poor ecosystem to their advantage.

\section{Ambalamanana}

One of us, CMK, carried out anthropological research in the village of Ambalamanana in Fianarantsoa Province, Madagascar in 2007. Ambalamanana is an agricultural village consisting of nine hamlets which include: Andaobato, Mielirano, Andambonifaly,
Andambohumainty, Amparihibe, and Akaramainty. The villages are bisected by River Sahemena, which flows north-to-south dividing the hamlets. Mielirano, Andambonifaly, and Amparihibe are due east while Akaramainty, Andaobato, Mangaranagarana, Anjorozoro, Soanototohizana, and Ambohimainty are due west. The community has a total of 102 households. The estimated population of the village is 650 people of which 54 percent at women (Table 1).

Table 1

\begin{tabular}{|c|c|c|c|}
\hline Hamlet & Household & Women & Men \\
\hline Mielirano & 33 & 74 & 57 \\
\hline Andambohifaly & 30 & 30 & 28 \\
\hline Andaobato & 5 & 8 & 7 \\
\hline Akaramainty & 3 & 4 & 4 \\
\hline Amparihibe & 16 & 9 & 7 \\
\hline Ambohimainty & 5 & 11 & 15 \\
\hline Mangarangarana & 3 & 27 & 4 \\
\hline Anjorozoro & 3 & 9 & 151 \\
\hline Soanotohizana & 4 & 176 & 9 \\
\hline Total & 102 & 9 & 10 \\
\hline
\end{tabular}

The village's recent history is best illustrated by in the numerous ruined houses in all the hamlets. The ruins point to community prosperity enjoyed in a not-to-distant past. This is bolstered by ethnohistorical and oral tradition evidence that point to good times when Ambalamanana peoples owned large herds of cattle, irrigated larges areas, and harvested surplus food stuffs, including rice, maize, manioc, tuners, potatoes, and many other food crops which they exported to the towns and cities in Madagascar (Bethel my August 10, 2007, Andaobato).

\section{Rice Irrigation in Ambalamanana}

The system of land tenure or division ensures that each household has landing the valley or farihy. The farihy is the most desirable land because it is permanently wet, requires little irrigation, and can be farmed all year round. In fairness to everyone, the community ensures that every household has an area allocated to them in the fairy. Other lands that are communally owned even though certain family rights are recognized include pastureland, tany vohitra. This is often in the hills or expansive land surrounding the village. No irrigation is required in maintaining the tany vohitra. Fallow land or tany tapoka is owned by respective households that first cultivated it. Permission must always be sought for anyone interested in developing a rice field or kipahi on such land. Under normal circumstances, such request is rarely turned down. Cases of leasing tanytapoka or terraces, tahalaka are quite common and in most instances, leases are granted due to absence of labor from the household that claims ownership. 
Rice is a major food crop in Ambalamanana. For the Betsileo (and indeed other highland peoples of Madagascar the Imerina, and Sihanaka) life without rice is unimaginable. The continued sustenance of the community in the central plateau is closely interwoven with the availability of water. The flow of water in the river, the irrigation canals, and the complex network of feeder channels is very critical.

In the village of Ambalamanana, everyone contributes their time and labor in the maintenance of irrigation canals. Individual households were responsible for maintaining respective feeder channels into their individual plots. Both men and women contribute labor usually on a communal and extended family basis.

\section{The Importance of Water to the Betsileo}

The Betsileo understand that working together is absolutely essential for the successful management of the rice fields. But the community has undergone major transformations which threaten to unseat long help rules and regulations guiding the use and consumption of water. The people of Ambalamanana enumerated several key issues that worried them about the volume, quality, and distribution of water in the community.

First, the increasing drought had affected the volume of water in the Sahemena River, resulting in the severe reduction of the volume of water in the canals and channels. As a result, many areas above the farihy in the Mielirano and Andaobato hamlets were no longer irrigated in the winter and the people must wait until the spring rains to prepare the land. The consequence of this is that large areas of cultivable land have reverted to tary taboka, fallow land. Water shortage is extreme in Ambalamanana in November, when, the volume in the Sahemena decreases to such levels that there is very little water to go around in the canals. Second, the villagers were concerned with the state of disrepair of the canal which channels water to Mielirano and Andaobato. The lack of materials, primarily cement and blocks, was attributed to poverty and cash flow which prevented the community from making modest repairs to the canals.

Third, the shortage of water has increased intra-household tensions and accusations of hoarding and stealing of those whose farm lets are closest to the canals. There is a causal relationship between declining soil fertility and seasonal water shortage with low yields and increased intra-community tensions. Communal cooperation has decreased, elders have lost moral, symbolic, and political power to organize labor especially of the young men to repair the canals. Increasing food shortage has forced many residents, especially young men and women to migrate to the cities, where they eke out their living as the working poor, underemployed and unemployed. The consequence has been a massive loss of labor pool. What are the consequences of these crises? Informants told CMK that communal cooperation presently occurs only at the level of organizing and managing ritual ceremonies but rarely at the level of work in the field. For example, "neighbors will be will to assist in case you provide food" (Bethelmy, Andaobato, born 1953).

Cattle rustling or the stealing of zebu was cited as the chief problem faced by the people of Ambalamanana. The sunken corrals that were once home to large cattle herds are now overgrown and empty owing to cattle theft. Without cattle the community cannot maintain the soil fertility in the fields. Since the land has been continuously cultivated for several hundred years, its current nutrient levels can no longer sustain sufficient crop yields without intensive use of manure or artificial fertilizer. Manure is largely procured from cow dung. Artificial fertilizers are too expensive for the villagers. Thus, cattle stealing threatens the villagers' source of livelihood. Without cattle, there can never be enough manure to fertile the rice fields. Many people are discouraged from owning zebu as they say this will attract thieves to their homes. Yet they are aware that without the mighty zebu, there won't be bountiful harvests. Those who take the risk to have zebu are unwilling to share their manure. The majority of the villagers shared the views cogently expressed by Andre Razafirahatratra of Ambohimainty thus: "Get rid of the cattle thieves and the future of the village will be self-evident (August 15, 2007). Poor governance was also blamed for the villages decline. Indeed the overall rating of performance by governmental institutions by the community was the lowest I have seen anywhere. The villagers were critical of the government and believed their condition has stayed the same or (deteriorated) since the new pro-business government was elected.

What happens when the system of water management fails due to mismanagement and climate change, when in our estimation, the village of Ambalamanana appears headed, unless there is some intervention? We illustrate this with a final example is drawn from Taita where during the 19th century severe drought led to the collapse of the irrigation agriculture with dire consequences. The failure of rain and shortage of water experienced in 19th century East Africa highlights the importance of water and the consequences of system collapse.

The Taita oral history recalls the 1880s and 1890s as the times of the worst droughts and famines. The famines referred to as the Mwakisenge were a defining moment in their history [50]. The famine resulted from severe drought; crop failure and widespread insecurity caused by slave raiding and associated warfare [33]. Drought led to the drying of most perennial rivers and streams, which forced people to relocate to the hills that still had a few running streams and springs. In the plains, droughts caused massive die-offs of wildlife. Crop failure and massive livestock wildlife die-offs disrupted intra and intergroup dynamics. Oral traditions report family feuds and conflicts over food that ended tragically. People sold or pawned their children into slavery to buy food. Massive death among children, pregnant women, and the elderly were reported everywhere in Tsavo country. According to historian Hollis Merritt (1975: 
100-102), the death toll among the Taita from the Mwakisenge famine reached 90 percent. People died in houses, on roadsides, in gardens and were left unburied as no one had strength to dig graves. The oral traditions recount that number of bodies were too numerous to be disposed hyenas[29].

Thus then and now, large-scale migration narratives are often closed intertwined with ecological or political catastrophes but underlying them are struggles to make a living during times of severe ecological stress. The Taita people for example, claim that those who were strong enough emigrated to their neighbors, the Taveta, Chagga, Pare, Akamba, and Giriama-wherever there was rumored to be food. Some went to the coast, were promised food by Swahili traders but promptly enslaved when they reached there [30].

A catastrophic famine occurred in the late 19th and early 20th century following rain failure in many parts of East Africa; extending from Juba-land in Somalia to north Tanganyika in the south and from coast inland towards Kikuyuland. This famine is remembered by several names: "Njala ya Madumbu"; "Njala ya Kibaba"; "Njala ya Mbelele; Enjala ya mutokaa." Like the Mwakisenge famine, the "every man for himself" mentality prevailed; people killed each other out of desperation. Parents killed their own children because they could not feed them. Cannibalism was reported. Groups of men would wait in the bush for young men to come near, attack them, and cut off their heads, hands and feet so no one could identify the victim if the group was caught. Upon his visit in 1890, Charles Hobley (1895:553) wrote about the devastation that drought had wrought on that people of Taita.

Some six or seven years back there was a great drought, and consequent famine at Taita; large numbers of the inhabitants died off, others moved temporarily to Taveta, Ukambani, and numbers of the children were sold into slavery to buy food. This period, which is known as the Mokusenga [Mwakisenge], and other similar periods in the more distant past, seems to have crippled the Wataita beyond their power of recuperation. Before the occurrence of these blows to their prosperity, large areas of ground at the base of various mountains-Ndi, Mbololo, Ndara, Kisigau, etc., were under complete cultivation; but the people have been so reduced in numbers that only about one-fifth to one-sixth of the former areas is at present under cultivation, the remainder having lapsed into tracks covered with grass, and here and there dotted with light scrub, the most extensive of these tracks being at Ndara. Before this time of drought, the mountain of Maungu was even inhabited; but the water supply failing for so long a period, they were obliged to abandon it and retire to Ndara.

\section{Conclusion}

Control of water, nutrient, and energy flows are the basis of human interaction with their natural environment. Management of water is at the heart of the evolution of societies and civilizations. In East Africa, many water control mechanisms remain local and predominantly use rain-fed agriculture. Management of water is at its simplest, for example using weeding to reduce evapo transpiration [7]. Archaeological and ethnographic evidence, however, shows that irrigation agricultural systems are and were in the recent past relatively widespread. Our ethnographic study from the central highland of Madagascar shows the continued operation of an intensive agricultural system, one which the ruins of Nyanga, Engaruka, and Mount Kasigau indicatewas considerably more widespread in sub-Saharan Africa than at present; however, such a system is vulnerable to stresses on water and soil fertility. Using Scarborough's [13] types of water management systems, we have examined the similarities and differences among these systems.

First, the East African systems are examples of multitasking systems [13]. In these systems, people perform the many tasks of managing complex agriculture but there is flexibility in their routines and decision-making; technological development is in general not extensive. At Engaruka, for example, fields and furrows were modified as river water flow and the needs of the settlements varied. In general, human labor was the most important form of energy input into this system and village leadership and lineage membership probably governed the application of labor to these systems. The semi-arid environment and tendency to soil depletion and drought probably drove a still relatively extensive, semi-mobile use of the landscape. The Engaruka complex was abandoned after little more than 300 years of settlement, yet during that time people had gradually transformed their landscape to make it more productive and resistant to irregularities in water. Although short-lived, the Engaruka complex shows the development of an "accretional" land and water use strategy based on human labor input and gradual ecological and economic change.

At Nyanga, the investment in stone-lined houses, extended household terraces and underground cattle pens, and the diversity of kinds of water management shows a greater emphasis on technological development of innovative household forms and methods of practicing both vlei farming and downslope irrigation. Here, there is a longer, more diverse history of settlement and also more evidence of social stratification. Most likely, decisions about management of water and human labor may have been controlled by local elites. In other words, the Nyanga example includes more investment in technology but also suggests that investments in labor organization- what Scarborough [13] calls labor tasking - may also have been more important. The Madagascar example represents an even further elaboration of labor tasking strategies that are necessitated by the labor-intensive farming of rice. These examples demonstrate the importance and diversity of water management practices in Africa, and show that in spite of arid environments, water management and agricultural intensification can survive and thrive in Africa. 


\section{Global Journal of Archaeology \& Anthropology}

\section{References}

1. Kusimba SB, Kusimba CM (2007) Intensification and Protohistoric Agropastoral Systems in East Africa. In: Thurston TL and Fisher CT (Eds.), Seeking a Richer Harvest: The Archaeology of Subsistence Intensification, Innovation, and Change. Springer, New York, USA, pp. 217-247.

2. Sutton JEG (1998) Engaruka: Irrigation Agriculture in the northern Tanzanian Rift Valley before the Maasai Era. Azania 33(1): 1-37.

3. Soper R (2007) The Terrace Builders of Nyanga. Harare: Weaver Press.

4. Fleuret P (1985) The social organization of water control in the Taita Hills, Kenya. American Ethnologist 12(1): 103-118.

5. Hakansson NT (1994) Grain, Cattle, and Power: Social Processes of Intensive Cultivation and Exchange in Precolonial East Africa. Journal of Anthropological Research 50(3): 249-276.

6. Flannery KV, Kirkby AV, Kirkby MJ, Williams AW (1967) Farming Systems and Political Growth in Ancient Oaxaca: Physiographic features and water-control techniques contributed to the rise of Zapotec Indian civilization. Science 158(3800): 445-454.

7. Kirby AVT (1973) The Use of Land and Water Resources in the Past and Present Valley of Oaxaca, Mexico. Museum of Anthropology, University of Michigan, USA.

8. Steward J H (1955) Theory of Culture Change. Urbana: University of Illinois Press.

9. Wittfogel K A (1957) Oriental Despotism: A Comparative Study of Total Power. New Haven: Yale University Press.

10. Schlee G (2004) Taking Sides and Constructing Identities: Reflections on Conflict Theory Journal of the Royal Anthropological Institute 10(1): 135-156.

11. Possehl G L (2000) The Drying up of the Sarasvati. In Naturalizing Disaster: From Drought to Famine in Southern India. In: G Bawden and R Reycraft (Eds.), Albuquerque: Maxwell Museum of Anthropology, Anthropological Papers No. 7, pp. 63-74.

12. Reycraft R (2000) Long-term Human Response to El Nino in South Coastal Peru. In Naturalizing Disaster: From Drought to Famine in Southern India. In: G Bawden and R Reycraft (Eds.), Albuquerque: Maxwell Museum of Anthropology, Anthropological Papers No. 7, pp. 99-120.

13. Scarborough VL (2003) The Flow of Power: Ancient Water Systems and Landscapes. Santa Fe: School of American Research Press, USA.

14. Clark JD (1977) The Spread of Food Production in sub-Saharan Africa. In: Konczacki Z and Konczacki JM (Eds.), An Economic History of Tropical Africa. Routledge, London, UK, pp. 3-13.

15. Terrell J, Hart JP, Barut S, Cellinese N, Curet A, et al. (2003) Domesticated Landscapes: The Subsistence Ecology of Plant and Animal Domestication. Journal of Archaeological Method and Theory 10(4): 323-368.

16. Morrison KD (2000) Environmental Disaster and the Archaeology of Human Response. In Naturalizing Disaster: From Drought to Famine in Southern India. In: G Bawden and R Reycraft (Eds.), Albuquerque: Maxwell Museum of Anthropology, Anthropological Papers No. 7, pp. 21-34.

17. Crumley C (1994) Historical Ecology: A Multidimensional Ecological Orientation. In: Crumley C (Ed.), Historical Ecology: Cultura Knowledge and Changing Landscapes. School of American Research, Santa Fe, Mexico, pp. 1-16.

18. Steward JH (1955) Theory of Culture Change. Urbana: University of Illinois Press, USA.
19. Adams WM (1989) Definition and development in African indigenous irrigation. Azania 24(1): 21-27.

20. Adams WM, Potkanski T, Sutton JEG (1994) Indigenous farmermanaged irrigation in Sonjo, Tanzania. The Gegraphical Journal 160(1): 17-32.

21. Millon R (1971) Variation in Social Responses to the Practice of Irrigation Agriculture. In: R. Woodbury (Ed.), Civilization in Arid Lands. Salt Lake City: University of Utah Anthropological Papers 62, pp. 56-88.

22. Crumley CL (1987) Dialectical Critique of Hierarchy. In: Patterson TC and Gailey CW (Eds.), Power Relations and State Formation. American Anthropological Association, New York, USA, pp. 155-159.

23. Crumley C (1995) Heterarchy and the Analysis of Complex Societies. In: Ehrenreich RM, Crumley CL, Levy JE (Eds.), Heterarchy and the Analysis of Complex Societies. Archaeological Papers of the American Anthropological Association, Washington, DC, USA, pp. 1-6.

24. Sutton JEG (1985) Irrigation and terracing in African agricultural history: Intensification, Specialization or Over-specialization? In: I $S$ Farrington (Ed.), Prehistoric Intensive Agriculture in the Tropics, British Archaeological Reports International Series 232. Oxford: British Archaeological Reports, pp. 737-764.

25. Sutton JEG (1989) Towards a history of cultivating the fields. Azania 24(1): 98-112.

26. Davies M (2008) The irrigation system of the Pokot, northwest Kenya. Azania: Archaeological Research in Africa 43(1): 50-76.

27. Davies MIJ (2012) Some thoughts on a 'useable' African archaeology: settlement, population and intensive farming among the Pokot of northwest Kenya. African Archaeological Review 29(4): 319-353.

28. Maddox G, Giblin JL, Kimambo I (1996) Custodians of the Land: Ecology and Culture in the History of Tanzania. Columbus: Ohio University Press, USA.

29. Merritt H (1975) A History of the Taita of Kenya to 1900. Ph.D. Dissertation, Indiana University. Ann Arbor, MI: University Microfilms International, USA.

30. Iliffe J (1979) A Modern History of Tanzania. Oxford University Press, Oxford, UK.

31. Ochieng WR (1990) Themes in Kenyan History. Nairobi: Heinemann Kenya, East Africa.

32. Kusimba CM, Kusimba SB, Wright DK (2004) The development and collapse of pre colonial ethnic mosaics in Tsavo, Kenya. Journal of African Archaeology 3(2): 243-265.

33. Kusimba CM and Kusimba SB (2005) Mosaics and Interactions: East Africa, 2000 b.p. to the Present. In: Stahl AB (Ed.), African Archaeology: A Critical Introduction, Blackwell Publishers, Boston, USA, pp. 394419.

34. Casey J (1998) The Ecology of Food Production in West Africa. In: Connah G (Ed.), Transformations in Africa : essays on Africa's later past. University of Leicester Press, London, UK, pp. 46-70.

35. Wagner G (1970) The Bantu of Western Kenya with Special Reference to the Vugusu and Logoli. Oxford: Oxford University Press, UK.

36. Schmidt P (1978) Historical Archaeology: A Structural Approach in an African Culture. Westport, Conn. Greenwood Press, USA.

37. Schmidt P (1980) Early Iron Age Settlements and Industrial Locales in West Lake. Tanzania Notes and Records 84-85: 325-340.

38. Schmidt P (1994) Historical Ecology and Landscape Transformation in Eastern Equatorial Africa. In: C Crumley (Ed.), Historical Ecology: Cultural Knowledge and Changing Landscapes. Santa Fe: School of American Research pp. 99-126. 
39. Perham M (1978) East African Journey: Kenya and Tanganyika, 19291930. London: Faber and Faber.

40. Gray RF (1963) The Sonjo of Tanganyika: An Anthropological Study of an Irrigation-Based Society. Oxford University Press, New York, USA.

41. Robertshaw P (1986) Engaruka revisited: Excavations of 1982. Azania 21(1): 1-26

42. Leakey LSB (1936) Preliminary report on examination of the Engaruka ruins. Tanganyika Notes and Records 1: 57-60.

43. Sassoon H (1967) New Views on Engaruka, Northern Tanzania Excavations Carried out for the Tanzania Government in 1964 and 1966. The Journal of African History 8(2): 201-217.

44. Soper R (2007) The Terrace Builders of Nyanga. Harare: Weaver Press.

45. Fleuret P (1985) The social organization of water control in the Taita Hills, Kenya. American Ethnologist 12(1): 103-118.

46. Dussubieux L, Kusimba CM, Gogte V, Kusimba SB, Gratuze B, et al (2008) The trading of ancient glass beads: new analytical data from south asian and east african soda-alumina glass beads. Archaeometry 50(5): 797-821.

47. Mack J (1986) Madagascar: Island of the Ancestors. London: British Museum Publications. In: McIntosh S (Ed.), Beyond Chiefdoms; Pathways to Complexity in Africa. Cambridge: Cambridge University Press.

48. Linton R (1929) Rice: A Malagasy Tradition. American Anthropologist 29(4): 654-660.

49. Hobley CW (1895) Upon a Visit to Tsavo and the Taita Highlands. The Geographical Journal 5(6): 545-561.

50. Scarborough VL (2000) Resilience, Resource Use, and Socioeconomic Organization. In: G Bawden and R Reycraft (Eds.), Naturalizing Disaster: From Drought to Famine in Southern India. Albuquerque: Maxwell Museum of Anthropology, Anthropological Papers No. 7, pp. 195-212.

\section{Your next submission with Juniper Publishers will reach you the below assets}

- Quality Editorial service

- Swift Peer Review

- Reprints availability

- E-prints Service

- Manuscript Podcast for convenient understanding

- Global attainment for your research

- Manuscript accessibility in different formats

( Pdf, E-pub, Full Text, Audio)

- Unceasing customer service

Track the below URL for one-step submission https://juniperpublishers.com/online-submission.php 